\title{
Vasa praevia: a case report and literature review
}

\author{
Kristina Norvilaitè ${ }^{1}$, \\ Aurelija Peštenyte $\dot{e}^{1}$, \\ Diana Bužinskienè $\dot{1}^{1,2}$, \\ Gražina Drąsutiene் $\dot{1}^{1,2}$, \\ Audronė Arlauskienè $\dot{1}^{1,2}$, \\ Tomas Poškus ${ }^{2,3}$, \\ Andrej Ostapenko ${ }^{2,3}$ \\ ${ }^{1}$ Centre of Obstetrics and Gynaecology, \\ Vilnius University Hospital \\ Santariškių Clinics, \\ Vilnius, Lithuania \\ ${ }^{2}$ Faculty of Medicine, \\ Vilnius University \\ ${ }^{3}$ Centre of Abdominal Surgery, \\ Vilnius University Hospital \\ Santariškių Clinics
}

Background. The aim of this article is to present a rare clinical case of vasa praevia as well as to assess the relevance of the problem by reviewing the latest literature sources.

Materials and methods. In this report we present a case of a 33-yearold woman diagnosed with vasa praevia at 33 weeks of pregnancy, after hospitalisation with preterm rupture of membranes following the delivery of a live healthy baby through a lower segment Caesarean section during 33rd week of gestation at Vilnius University Hospital Santariškiu Clinics. We investigated all the documentation of the patient before and after delivery.

Results and conclusions. Vasa praevia is a rather rare pathology which is likely to occur during pregnancy, may result in heavy bleeding and be particularly threatening to the fetus life. A timely diagnosis for these women is essential. The gold standard for vasa praevia diagnosis is the fetal ultrasound scan. Vasa praevia pathology is found during the routine second trimester ultrasound check-up. The selection of proper tactics applied during pregnancy care is essential. At the gestational age of 28-32, it is advisable to mature fetal lungs as well as the fetus condition should be investigated by a perinatologist. The mode of delivery is the C-section which tends to reduce the frequency of possible complications.

Keywords: vasa praevia, pregnancy, bleeding, obstetrical management, childbirth, newborn outcomes

\section{INTRODUCTION}

Even though vasa praevia is considered to be a rather rare pathology observed in the obstetrical practice, due to its strong likelihood of bleeding it may be life-threatening to the fetus. The timely diagnosis of this pathology is of high importance. Making a timely diagnosis significantly improves pregnancy outcomes. Modern ultrasound technology allows an accurate diagnosis of this pathology before childbirth. Monitoring of this mode of

Correspondence to: Kristina Norvilaite, Centre of Obstetrics and Gynaecology, Vilnius University Hospital Santariškių Clinics, 2 Santariškių Street, LT-08661 Vilnius, Lithuania. E-mail: kristina.norvilaite@gmail.com high risk pregnancy is essential in terms of re-assessing the condition of the fetus and the entire obstetric situation to make a decision on the completion time of pregnancy.

\section{A CLINICAL CASE}

A 33-year-old patient, V. P., was hospitalised at the Pregnancy Pathology Unit of Vilnius University Hospital Santariškių Clinics (VUL SK) during her 33rd week of pregnancy due to premature leakage of amniotic fluid, irregular uterine contractions, an increased amount of vaginal discharge, leg muscle cramps. The fetal movements were felt well. It was the second pregnancy. The woman gave birth once via a cesarean section operation in 2006. 
Pregnancy monitoring was started from the 9th week of gestation. At that fetal age stage, the pregnant woman suffered from back pains, consulted a neurologist, was diagnosed with radiculopathy, however, no specific treatment was administered. A fetal ultrasound scan was performed during weeks 20 and 31 with no pathology observed. The woman suffered from an acute viral respiratory infection during the 30th week of gestation, and treatment with gelomyrtol capsules was administered. On the 32nd week, common anemia was diagnosed which was treated with iron preparations.

Prior to conception, the subject suffered from chickenpox, flu; in 2004, she underwent a surgery on the left ovarian cyst, and laparoscopic cystectomy was performed. Allergic reactions to penicillin and ampicillin were observed. The pregnant woman's husband, aged 35, was generally healthy, smoked up to 10 cigarettes a day.

General examination showed satisfactory general condition: temperature $37.0^{\circ} \mathrm{C}$, rhythmic heart activity, no murmur, heart rate $78 / \mathrm{min}$, arterial blood pressure 130/80 $\mathrm{mmHg}$, normal uterine tone, palpation of the uterus triggered contraction response. On vaginal examination with a speculum, the external genitals and vagina were found to be with no visible lesions, amniotic fluid was observed in the vagina, and uterine cervix was partially centered and closed. Sonography showed that the cervical length was $2.1 \mathrm{~cm}$, the internal cavity had the shape of a funnel, $0.5 \mathrm{~cm}$ in width, and the cephalic fetal position was at the entrance to the small pelvis. Below the cephalic fetal position, the colour Doppler monitoring showed the leading umbilical cord blood vessels. A nonstress fetal test recorded in the reception room was reactive, the fetal heart tone was $146 / \mathrm{min}$.

Diagnosed with premature pregnancy resulting from the flow of the amniotic fluid, the pregnant woman was admitted to the Pregnancy Pathology Unit of the Obstetrics and Gynaecology Clinic of VUL SK. The management involving pregnancy care, investigation and treatment was designed. The subject was administered bed rest, was observed for the development of regular spontaneous labour activity, the fetal status was assessed by registering a nonstress fetal test. Fetal lung maturation was carried out with intramuscular injections of dexamethasone of $12 \mathrm{mg}$ every 12 hours 2 times per day, tocolysis was given by $20 \mathrm{mg}$ of nifedipine every $30 \mathrm{~min}$ twice, followed by $10 \mathrm{mg}$ of nifedipine every 2 hours
4 times. Antibacterial treatment was carried out with $2 \mathrm{~g}$ of ampicillin intravenously every 8 hours.

The following investigations were performed: a common blood test, a common urine test, vaginal culture to determine group B beta hemolytic streptococcus, fetal ultrasound. The results of the common blood test were as follows: Leu $13.44^{\star} 10^{9} / \mathrm{l}, \mathrm{Hb}$ $121 \mathrm{~g} / \mathrm{l}$, PLT $199^{\star} 10^{9} / \mathrm{l}$, C-reactive protein $1.3 \mathrm{mg} / \mathrm{l}$. The common urine test was within normal limits. The vaginal culture showed the growth of Streptococcus beta-haemolyticus $\mathrm{Gr}$. B, the antibioticogram revealed the bacterium's sensitivity to penicillin. The fetal ultrasound scan showed that the pregnancy duration according to the last menstrual period was 34 weeks and 1 day, the fetus's physical development was consistent with the standards of 34 weeks and 2 days. The fetus was single, in a longitudinal, cephalic fetal position, with fetal heart activity, movement, breathing functions observed. The fetal biometry BPM was 8.3; HC 29.8; AC 31.2; FL $6.7 \mathrm{~cm}$. The estimated weight was $2,462 \mathrm{~g} \pm 359$. The deepest amniotic pocket was $2.1 \mathrm{~cm}$, and the amniotic fluid index was $4.7 \mathrm{~cm}$. Doplerometry data were the following: fetal heart rate 141 beats/min, a.umbilicalis S/D 1.8, a.umbilicalis RI 0.47, a.umbilicalis PI 0.62 . The placenta was observed on the front wall, attached low, close to the bottom edge of the scar. The coloured doplerometry revealed leading umbilical cord blood vessels. Cervical length was $2.1 \mathrm{~cm}$, closed.

After taking into account the obstetric situation, including the assessment of 34-week pregnancy, premature leakage of amniotic fluid, umbilical cord vessels presentation, the presence of a scar in the uterus as a result of a previous Caesarean section, a general discussion was held and a decision was made to end the pregnancy by a Caesarean section. Typically, an incision was performed in the lower uterine segment, with vasa praevia detected and preserved intact, the fetus's birth was aided by his head in $1 \mathrm{~min}$. A female newborn weighing 2,320 grams and $45 \mathrm{~cm}$ tall was born, assessed by Apgar $1 \mathrm{~min}$ after birth scored 8, 5 min later it was 9. The umbilical cord arterial $\mathrm{pH}$ was 7.35. The placenta was solid, $600 \mathrm{~g}$ of weight, had been removed manually. The blood loss was $600 \mathrm{ml}$. When examining the placenta, a membranous cord anchorage was observed (Figs. 1, 2). The placenta with membranes and the umbilical cord were sent for histological examination. The final diagnosis of the pathology was the following: placenta's examination revealed the presence of calcinates, membranous 

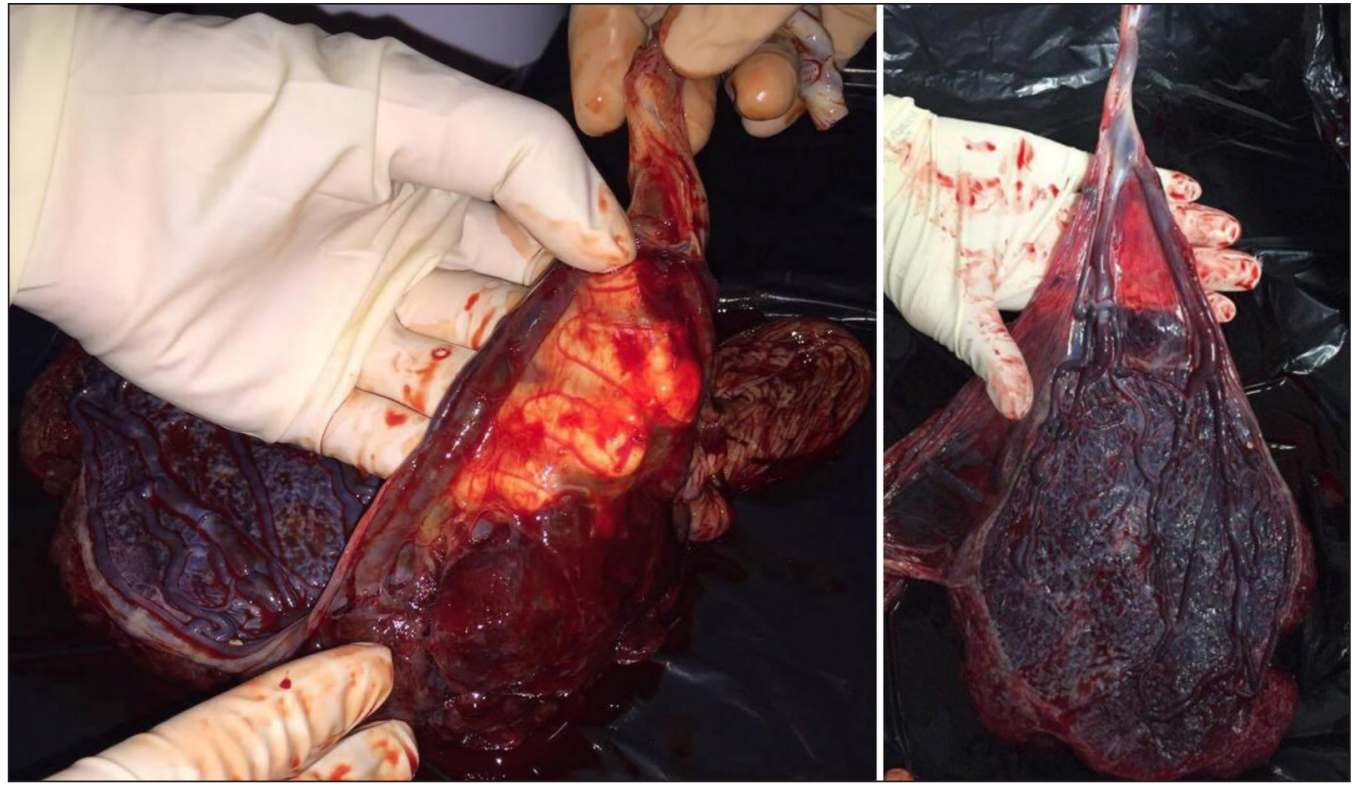

Figs. 1, 2. The placenta with membranes and the umbilical cord

cord anchorage, no inflammatory infiltration in the umbilical cord and the membranes. Placental chorionic villi showed a normal histological structure with scarce intervillous fibrinoid compilations and calcinates. No inflammatory infiltration was detected in the chorionic plate, umbilical cord and membranes. The umbilical cord at the branching site around the blood vessels did not show any Wharton's substance.

\section{LITERATURE REVIEW AND DISCUSSION}

The "vasa praevia" term is derived from the Latin word "vasa", meaning the blood vessels, "prae" is prior, "via" means passages (1). This is a pathology that may occur during pregnancy when umbilical cord blood vessels in fetal membranes are located lower than the presenting part of the fetus (2) (Figs. 3, 4). The incidence of the condition estimates one case in 1275-5000 births (3). The state is characterised by the fact that the blood vessels contained in the fetal membranes are loose, uncoated by placental tissues or Wharton's jelly (4). The scholarly literature describes two types of vasa praevia: first, when the umbilical cord blood vessels emerging from the placenta in the form of membranes are later transformed into an umbilical cord; second, where the blood vessels emerging from the main placenta via membranes are heading towards the additional segment of the placenta (one or more). In both cases, the blood vessels cover the cervix or reach as far as $2 \mathrm{~cm}$ till the internal orifice (5). This condition results in a life-threatening pathology for the fetus because, during contractions, the leading part of the fetus can press the fetal blood vessels and cause their thrombosis (6), or they can be damaged by rupture of the fetal membranes, which would lead to fetal hypoxia, bradycardia, hemorrhage and even death in $60-100 \%$ of cases $(5,7,8)$.

The first vascular praevia case was described in 1801, while the first ultrasound diagnosis of this clinical case was conducted in $1987(2,5)$. The pathogenesis is unknown (7). It is considered that vascular praevia occurs when, at the beginning of pregnancy, after the formation of the placenta, it covers the internal cervical opening. Since this area has a low degree of vascularisation, with the growth of the uterus, the placenta in the uterus is moved toward a better vascularised area, the remaining placental tissue on the cervix atrophies and only umbilical cord blood vessels attached to the membranes remain $(1,2)$.

Also, the scholars describe a number of vasa praevia risk factors: membranous umbilical cord anchorage, additional segments of the placenta (two or more), a low-attached low placenta or placenta praevia, twins, assisted reproduction procedures (9). The main risk factors are membranous cord anchorage and the multi-segmental placenta (5). After assisted reproduction procedures, the incidence of this disease is estimated as 1 case in 201-300 

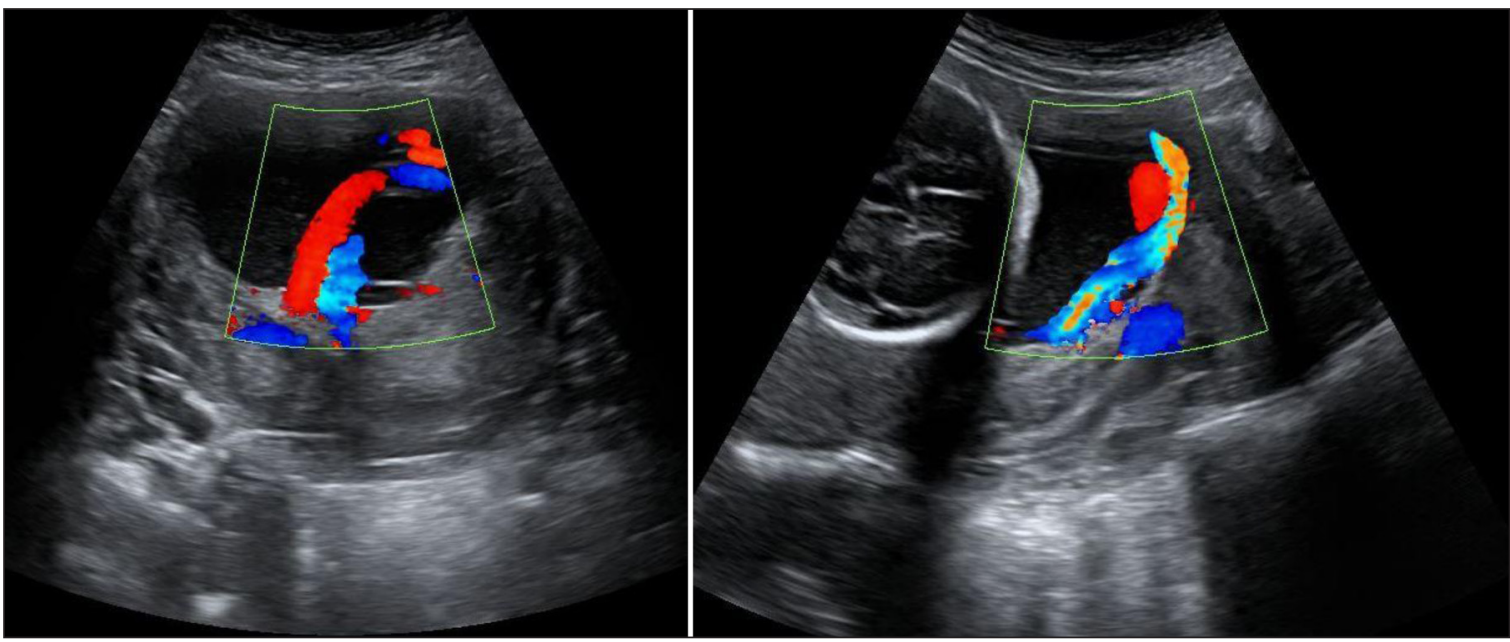

Figs. 3, 4. Ultrasound scan showing umbilical cord blood vessels in fetal membranes that are located lower than the presenting part of the fetus

pregnancies $(5,2,10)$. During delivery, if vasa praevia is diagnosed, in $60 \%$ of the cases, in the second trimester of pregnancy, a low placental anchorage or placenta praevia (5), various fetal anomalies (10) were diagnosed.

A classic clinical symptom is painless uterine bleeding with dark blood and a sudden deterioration of the condition of the fetus (11). In case of bleeding from the uterus, in most common cases it is due to placenta praevia or detachment. However, it should be taken into account that it is the most common vasa praevia clinical sign. The fetus suddenly loses a large amount of blood, the cardiotocogram records the sinusoidal fetal heart rate (9). The fetal blood loss of $100 \mathrm{ml}$ or more can lead to hemorrhagic shock and death (10). Vasa praevia can be diagnosed on the vaginal examination, where the pulsation of blood vessels is palpable as fetal praevia.

Vasa praevia is diagnosed by assessing clinical signs, during vaginal, ultrasound (US) examination, amnioscopy or magnetic resonance imaging (MRI) (10). Ultrasound examination is a golden diagnostic standard for vasa praevia (11). In the second trimester (18-20 weeks), it is essential to determine by ultrasound the exact cord attachment site in all pregnant women (2). The pathology by ultrasound is diagnosed in almost $100 \%$ of the cases (10). In the presence of vasa praevia, above the internal cervical orifice, blood vessels will be visible (2). On suspicion of vasa praevia or at high risk to pregnancy (i. e. low placental anchorage, condition after IVF, multiple pregnancies, multisegmental placenta, bleeding from the vagina) or on abdominal ultrasound scan failing to observe a cord attachment point, (1) it is appropriate to perform transvaginal echoscopy with colour doplerometry $2 \mathrm{D}$ and $3 \mathrm{D}(10,12)$. In the case of vasa praevia detected on transvaginal ultrasound examination, vertically above the internal cervical orifice, a blood flow is clearly visible (12). In some cases, magnetic resonance imaging helps to clarify the diagnosis. This investigation has some advantages over ultrasound due to its accurate description of the vessels, the location, direction, placenta, its structure and the point of attachment, segments and their distribution. However, it is an expensive, relatively not easily accessible and long-lasting visual examination, which generally does not have greater advantages compared to ultrasound colour doplerometry (13).

A typical image of vessels may be similar to a cord loop, so in order to clarify the diagnosis, the position of a pregnant woman should be changed - in the case of vasa praevia, the image remains the same (10). In order to differentiate from the cervix-uterine varicose veins, a transvaginal colour doplerometry method is employed to compare the blood flow in these veins, to the fetus and the mother's blood flow. In the case of vasa praevia, the blood flow will be the same as the umbilical cord blood flow (14).

When a pregnant woman is diagnosed with vasa praevia, the pregnancy must be completed by performing a planned Caesarean section surgery in a tertiary level hospital that provides a possibility to 
have a fetal blood transfusion performed (5). If this pathology is diagnosed before the onset of clinical signs and upon the scheduled completion of pregnancy, the neonatal survival rate is $96-97 \%(1,5$, $10,15)$. The optimum time for the completion of pregnancy has not been established (5). The evaluation of the available data shows that the optimal scheduled time to perform a Caesarean section is 34-37 weeks of gestation. It is necessary to administer medication targeted at the fetal lung maturation (5). This is a high-risk pregnancy as along with the growing fetus, the likelihood of premature leakage of amniotic fluid or fetal blood loss is also increasingly growing (10), thus the fetal lung maturation with dexamethasone should be performed from the 28 th to the 32 nd week $(5,10,14,15)$. In the case of clinical signs, a pregnant woman shall be admitted to hospital immediately, the fetal condition shall be monitored by a continuous fetal cardio-monitor, if possible, the concentration of fetal hemoglobin in the blood shall be determined (10).

In the absence of clinical signs, pregnant women should be recommended bed rest and preventive hospitalisation during weeks 30-34 to carry out intermittent fetal monitoring (nonstress test 2-3 times per day) and fetal ultrasound examination $(5,10,15-17)$. The indications of completing the pregnancy via the emergency Caesarean section are as follows: labour activity, preterm leakage of amniotic fluid, unstable fetal condition - variable recurring decelerations recorded by a nonstress test, which persist through the introduction of tocolysis. Other indications may be as follows: bleeding from the uterus, fetal tachycardia, sinusoidal type of fetal heart rate, fetal anemia, confirmed by Apt or Kleihauer-Betke tests (14). A lower transverse laparotomy and a uterine incision in the lower uterine segment are performed after taking into account the $3 \mathrm{D}$ ultrasound images where the leading blood vessels are visualised seeking to reduce the possibility of damaging them (18). In the case of vasa praevia damage occurrence during surgery, bleeding shall be immediately arrested by sealing vessels with the instrument until the fetus is pulled out (5).

\section{CONCLUSIONS}

Cord blood vessels presentation is a quite rare clinical condition, however, it is hazardous to the fetus or the newborn because it increases the probability of fetal death during pregnancy or childbirth. Upon an ultrasound diagnosis of this pathology, pregnancy must be monitored as a high-risk pregnancy by selecting appropriate completion tactics. The safest way to complete this mode of pregnancy is a scheduled Caesarean section prior to the onset of labour or prior to the manifestation of vasa praevia clinical signs.

Received 3 February 2016 Accepted 21 March 2016

\section{References}

1. Donnolley N, Halliday EL, Oyelese Y. Vasa Praevia: a descriptive review of existing literature and the evolving role of ultrasound in prenatal screening. AJUM. 2013; 16(2): 71-6.

2. Derbala Y, Grochal F, Jeanty Ph. Vasa previa. J Prenat Med. 2007; 1(1): 2-13.

3. Ruiter L, Kok N, Limpens J, Derks JB, de Graaf IM, Mol BW, Pajkrt E. A systematic review on the diagnostic accuracy of ultrasound in the diagnosis of vasa previa. Ultrasound Obstet Gynecol. 2015; 45: $516-22$.

4. Ebbing C, Kiserud T, Johnsen SL, Albrechtsen S, Rasmussen S. Prevalence, risk factors and outcomes of velamentous and marginal cord insertions: A population-based study of 634,741 pregnancies. PLoS One. 2013; 8: e70380.

5. Sinkey RG, Odibo OA, Dashe J. Diagnosis and management of vasa previa. Am J Obstet Gynecol. 2015; 37: 615-9.

6. Lijoi AF, Brady J. Vasa previa diagnosis and management. J Am Board Fam Pract. 2003; 16(6): 543-8.

7. Kelekci S, Aydogmus S, Eris S, Şeyhanlı ZÇ, Aydogmus $\mathrm{H}$, Şengul $\mathrm{M}$. The importance of prenatal diagnosis in the management of vasa previa: case report. JSM Clin Case Rep. 2014; 2(6): 1071.

8. Royal College of Obstetricians and Gynaecologists. Placenta praevia, placenta praevia accreta and vasa praevia: diagnosis and management (Green-top Guideline No. 27). London: RCOG; 2011.

9. Modanlou HD, Murata Y. Sinusoidal heart rate pattern: Reappraisal of its definition and clinical significance. J Obstet Gynaecol. 2014; 30(3): 169-80.

10. Gagnon R, Morin L, Bly S, Butt K, Cargill YM, Denis $\mathrm{N}$, et al. Guidelines for the management of vasa 
previa. J Obstet Gynaecol Can. 2009 Aug; 31(8): 748-60.

11. Othman M, Khojah S, Fathi T, Alkholy T, Aljayar L, Alhazmi J. Vasa praevia; case report. WebmedCentral Obstet Gynaecol. 2014; 5(5): WMC004643.

12. Oyelese Y, Chavez MR, Yeo L, Giannina G, Kontopoulos EV, Smulian JC, Scorza WE. Three-dimensional sonographic diagnosis of vasa previa. Ultrasound Obstet Gynecol. 2004; 24(2): 211-5.

13. Oyelesea Y, Jhab RC, Moxleya MD, Colleaa JV, Queenana JT. Magnetic resonance imaging of vasa praevia. BJOG. 2003; 110: 1127-8.

14. Podrasky AE, Javitt MC, Glanc P, Dubinsky T, Harisinghani MG, Harris RD, et al.; Expert Panel on Women's Imaging. ACR Appropriateness Criteria ${ }^{\circ}$ second and third trimester bleeding [online publication]. Reston (VA): American College of Radiology (ACR); 2013. 13 p.

15. Robinson BK, Grobman WA. Effectiveness of timing strategies for delivery of individuals with vasa previa. Obstet Gynecol. 2011; 117: 542-9.

16. Royal College of Obstetricians and Gynaecologists. Antepartum Haemorrhage (Green-top Guideline No. 63). London: RCOG; 2011.

17. Cunningham F, Leveno K, Bloom S, Hauth J, Rouse D, Spong C. Williams Obstetrics. 23rd ed. McGraw-Hill Education; 2009. p. 583.

18. Neuhausser WM, Baxi LV. A close call: does the location of incision at cesarean delivery matter in patients with vasa previa? A case report. F1000Res. 2013; 2: 267.
Kristina Norvilaitė, Aurelija Peštenytė, Diana Bužinskienė, Gražina Drąsutienė, Audronė Arlauskienė, Tomas Poškus, Andrej Ostapenko

\section{VIRKŠTELĖS KRAUJAGYSLIŲ PIRMEIGA: KLINIKINIS ATVEJIS IR LITERATŪROS APŽVALGA}

\section{Santrauka}

Tikslas. Straipsnio tikslas - pristatyti retą virkštelès kraujagyslių pirmeigos klinikinį atveji, apžvelgti naujausius literatūros šaltinius ir ịvertinti problemos aktualumą.

Medžiaga ir metodai. Straipsnyje pateikiamas klinikinis 33 metų moters atvejis, kuriai 33-čią neštumo savaitę diagnozuota virkštelès kraujagyslių pirmeiga, po to, kai ji buvo hospitalizuota dèl priešlaikinio vaisiaus membranų plyšimo ir pagimdè gyvą, 33 gestacijos savaičių, sveiką naujagimį per apatinio segmento Cezario pjūvị Vilniaus universiteto Santariškių klinikose. Aprašant atveji retrospektyviai išnagrinèti visi moters dokumentai iki ir po gimdymo.

Rezultatai ir išvados. Virkštelès kraujagyslių pirmeiga - labai reta patologija, pasitaikanti néštumo metu, ypač grèsminga vaisiaus gyvybei dèl didelès jo nukraujavimo rizikos. Šią patologiją svarbu laiku diagnozuoti. Patikimiausias diagnostikos būdas yra ultragarsinis tyrimas. Ši patologija dažniausiai nustatoma antrojo něštumo trimestro ultragarsinès patikros metu. Pasirinkti tinkamą nèštumo priežiūros ir užbaigimo taktiką labai svarbu. Rekomenduojama atlikti vaisiaus plaučiu brandinimą 28-32 nèštumo savaitę, vaisiaus būklè turi būti stebima perinatologo. Cezario pjūvio operacija labai sumažina galimų komplikacijų dažnị.

Raktažodžiai: virkštelès kraujagyslių pirmeiga, nèštumas, kraujavimas, akušerinè taktika, gimdymas, naujagimio išeitys 